\title{
Effects of Planting Time and Cultivar on Leaf Physiology and Seed Yield of Soybean (Glycine max. (L.) Merr)
}

\author{
Eko Srihartanto ${ }^{1,2 *}$ and Didik Indradewa ${ }^{3}$ \\ ${ }^{1}$ Assesment Institute of Agriculture Technology Yogyakarta, Indonesian Ministry of Agriculture; \\ ${ }^{2}$ Magister Student of Agronomy, Postgraduate, Faculty of Agriculture, Universitas Gadjah Mada, Yogyakarta, \\ Indonesia; ${ }^{3}$ Faculty of Agriculture, Universitas Gadjah Mada, Yogyakarta, Indonesia
}

*Corresponding author: srihartantoeko@yahoo.co.id

\begin{abstract}
The use of adaptive soybean cultivars with appropriate planting time on dry land can enhance the improvement of soybean growth and yield. This study aimed to determine changes in leaf physiological character and soybean yield as affected by different planting time and superior soybean cultivars. The experiment was conducted on the dry land of Inceptisol in Gunungkidul from November 2018 to March 2019. The experiment was arranged in a Split Plot Design with the main plot arranged in a Randomized Complete Block Design (RCBD) with three (3) replications. The main plots consisted of three planting times, i.e. early planting time-Pranoto Mongso, midldle planting time-Farmer Method and late planting-Katam Terpadu. The subplots consisted of four soybean cultivars, namely Anjasmoro, Argomulyo, Grobogan and Dega-1. The fertilizers used were organic fertilizer $\left(2 \mathrm{t} \mathrm{ha}^{-1}\right)$, Urea $(50 \mathrm{~kg}$ $\left.\mathrm{ha}^{-1}\right)$ and $\mathrm{KCl}\left(50 \mathrm{~kg} \mathrm{ha}^{-1}\right)$. The results showed that the treatment of planting time and cultivar could increase leaf physiological activity, particularly the number of leaves, total leaf area, leaf area index and plant growth rate. Early planting time-Pranoto Mongso and middle planting time-Farmers Method produced higher plant dry weight $(20.11 \mathrm{~g} ; 24.21 \mathrm{~g})$ and seed yields per plant $(29.11 \mathrm{~g} ; 26.75 \mathrm{~g})$ than late planting (Katam Terpadu) did (20.30 g). Meanwhile, cultivar Dega-1 had higher seed yields per plant (30.11 g) than cultivar Grobogan (28.39 g), Argomulyo (23.35 g) and Anjasmoro (19.79 g) did.
\end{abstract}

Keywords: cultivars, leaf physiology, planting time, seed yields

Cite this as: Srihartanto, E., \& Indradewa, D. (2019). Effects of Planting Time and Cultivar on Leaf Physiology and Seed Yield of Soybean (Glycine max. (L.) Merr). Caraka Tani: Journal of Sustainable Agriculture, 34(2), 115-127. doi: http://dx.doi.org/10.20961/carakatani.v34i2.28974

\section{INTRODUCTION}

Soybean (Glycine max. (L.) Merr.) is a source of vegetable protein that is very popular among the people in Indonesia. Domestic soybean production has not been able to meet the needs for food and feed raw materials because local soybean production only reaches 887.42-963.18 thousand tons per year while the demand per year reaches 2.2-2.4 million tons so that it is necessary to import soybeans around 1.96 million tons (PUSDATIN KEMENTAN, 2016). Efforts to increase soybean productivity on upland are continuously carried out according to the principles of sustainable agriculture. Sustainable agriculture concerns on the effective, productive and inexpensive external input systems; respects local wisdom and involves the role of farmers in the management and conservation of natural resources and agriculture (Reijntjes et al., 1999; Budiasa, 2011) and is socially, economically and institutionally accepted (Purwanto and Cahyono, 2012). Strategies to intensify soybean production can be achieved by increasing planting area, enhancing productivity, reducing yield gap,

\footnotetext{
* Received for publication March 29, 2019

Accepted after corrections May 15, 2019
} 
increasing stability and decreasing yield loss. Environmental conditions can determine the yield of crop seeds, in which stress due to environmental conditions can reduce the components of soybean yield (Nugrahaeni et al., 2012). One of the technologies to increase soybean productivity is insuring the availability of water for plants in dry land through a strategy to regulate the planting time and the use of adaptive superior soybean cultivars.

Soybeans are generally planted in the rainy season on dry land, but they are planted on paddy fields in the dry season. The problem of soybean cultivation on dry land is the availability of water, and thus it is necessary to determine the proper planting time by paying attention to rainfall and soil moisture content. Water requirement during the vegetative period (up to 35 days) is $126 \mathrm{~mm}$ and during generative growth (age 35-85 days) is $203 \mathrm{~mm}$ (Boote et al., 1982). The water need of the plant at the beginning of the period of growth is low and it increases until the canopy of the leaves develops and closes completely. The need for water then decreases until near harvest. During the growth between 85 and 100 days, soybean plants require water from $450-700 \mathrm{~mm}$ (Doorenbos and Kassam, 1979; Ludwig et al., 2011), $300-450 \mathrm{~mm}$ or $2.5-3.3 \mathrm{~mm}$ day $^{-1}$ with optimum moisture content revolving around a water potential voltage of 0.3-0.5 atm (Zandstra, 1982; Fagi and Tangkuman, 1985). Soybean plants necessitate average temperature of $23^{\circ}$ $25^{\circ} \mathrm{C}$; altitude of $1-700$ meter above sea level; rainfall of 1,500-2,000 mm year-1 or 300-400 mm planting season ${ }^{-1}$; good drainage channel; soil moisture content of 70-80\% from field capacity; soil $\mathrm{pH}$ of 6.0-6.5; high content of organic matter, $\mathrm{N}, \mathrm{P}, \mathrm{K}, \mathrm{Ca}$ and $\mathrm{Mg}$; Al saturation of $<8 \%$ and a condition in whict they are not shaded under trees with a tolerance limit of 0-8\% (Nurhayati, 2010).

Water shortage is a problem that inhibits plant growth and yield which causes low production. Sufficient soil moisture content during flowering and pod filling can increase seed yield (Wijewardana et al., 2018). Drought stress that occurs from the maximum vegetative phase until flowering phase can reduce soybean seed yield (Jha et al., 2018) and cause high yield gaps (Sentelhas et al., 2015). Plants that experience drought will shrink their stomata to reduce water loss through transpiration. This stomata shrinkage will also reduce $\mathrm{CO}_{2}$ diffusion and photosynthate production, and consequently, this slows plant growth. The phase that is most sensitive to water shortage is the final phase of pod development and middle phase of seed filling. At the final phase, soybean plants normally abort $<50 \%$ of flowers and pods, but under conditions of drought stress, the fall of flowers and pods can reach 70-80\% (Sudarsono and Widoretno, 2003). Efforts to ensure the availability of rainwater during the growth of soybean crops on dry land can be done by using adaptive and high-yielded soybean cultivars planted in approriate time.

The selection of adaptive cultivars is needed to avoid the negative impact of stress. In diverse agroclimatic environments, adaptive cultivars are required. The resistance of adaptive cultivar can be enhanced through cultivar selection and genetic improvement (Gilbert et al., 2011; Lehmann et al., 2013; Devi et al., 2014). Basically, there are three strategies to improve crop resistance to drought, i.e. drought escape, drought avoidance and drought tolerance. Environmental conditions affect the strategy of plant resistance mechanisms to continue implementing the growth process (Levitt, 1980; Turner, 1997; Kholova, 2010). In drought escape, plant is able to complete its life cycle before drought stress occurs such as by flowering earlier. Some plants choose dormancy to avoid stress or complete the reproductive phase before drought occurs (Manavalan et al., 2009). In drought avoidance, plants avoid water shortages or maintain tissue water potential by developing morphological, anatomical and biochemical processes as well as certain physiological processes such as reducing transpiration and reducing absorption of radiation by rolling up their leaves (Clarke, 1986; Zou et al., 2011), decreasing leaf area (Saruhan et al., 2009), developing extensive roots, maximizing root propagation (Blum, 2005; Goodger and Schachtman, 2015) and using water efficiently. In drought tolerance, plants adjust biochemical processes because of drought stress, for examples, by degrading chlorophyll, inducing oxidative enzymes and osmoprotecting (osmotic adjustment). In overcoming drought stress, drought tolerance can control the stomatal function so that it can improve the efficiency of water use or stomatal conductance quickly when drought stress begins to decrease (Yordanov et al., 2000). Reducing water consumption is one of plant mechanisms in increasing resistance to drought stress (Zhu et al., 2012). The closure of 
the stomata inhibits photosynthesis and limits the availability of $\mathrm{CO}_{2}$ in chloroplast. The experiment in this research aimed to determine changes in leaf physiological characteristics and soybean yields as affected by different superior soybean cultivars and planting time.

\section{MATERIALS AND METHOD}

The study was conducted in dry land of Central Zone (Ledok Wonosari), Gunungkidul, D.I. Yogyakarta, from October 2018 to March 2019. The experiment was arranged in a Split Plot Design with the main plot of three planting times (early-Pranoto Mongso, middle-Farmer Method and late-Katam Terpadu) and subplots of four soybean cultivars (Anjasmoro, Argomulyo, Grobogan and Dega-1). The treatment was replicated in three blocks as replications so that the total 36 treatment combinations were applied. The initial treatment of Pranoto Mongso was carried out on 7 November 2018 (November I) coinciding with the calendar of mongso kalimo "Semplah" or the fifth season. The initial treatment of Farmer Method started after successive rains for 3-5 days with heavy to very thick intensity on 14 November 2018 (November II) while the treatment of Katam Terpadu was carried out on 5 December 2018 (December I) according to the forecast of the beginning of the rainy season in which the rainfall was $>35 \mathrm{~mm}$ for one dasarian (10 days in a row) and was followed by the next two dasarians.

Soil tillage was carried out in a simple way (minimum tillage) and the planting space was 40 $\mathrm{cm} \times 20 \mathrm{~cm}$ with three seeds per planting hole. The experimental plot was $4 \mathrm{~m} \times 2.5 \mathrm{~m}$ with bed height of $30 \mathrm{~cm}$. The distance between beds was $20 \mathrm{~cm}$ and the distance between blocks was $1 \mathrm{~m}$. The fertilizers used were Urea $50 \mathrm{~kg} \mathrm{ha}^{-1}, \mathrm{KCl} 50 \mathrm{~kg}$ $\mathrm{ha}^{-1}$, organic fertilizer $2 \mathrm{t} \mathrm{ha}^{-1}$ and legin (Rhizobium inoculants) $5 \mathrm{~g} \mathrm{~kg}^{-1}$ seeds. Urea fertilization was given twice, i.e. 0.5 parts during planting and the restat 14 days after planting (dap). $\mathrm{KCl}$ fertilization was given once at the planting time. Organic fertilizer was provided to the planting hole as a cover for soybean planting. Data obtained from observation were tested using analysis of variance (ANOVA) for split plot designs with main plots arranged in a Randomized Complete Block Design (RCBD). The mean comparison for the main factors and subfactors was performed using Duncan Multiple Range Test and the result was displayed in table. Data analysis was carried out using SAS software (SAS Institute Inc, 1985). Data visualization was done using Microsoft Excel 2010 software. The 95\% confidence level was used to express significant differences.

\section{RESULTS AND DISCUSSION}

\section{Number of leaves per plant}

Data in Table 1 show that Anjasmoro cultivars have the highest number of leaves per plant compared to other cultivars. Soybeans (42 dap) planted at early planting time-Pranoto Mongso and at middle planting time-Farmer Method had more leaves than those planted at late planting time-Katam Terpadu.

Table 1 Number of leaves per plant $\left(n^{\circ}\right)$ at 14 and 42 dap

\begin{tabular}{|c|c|c|}
\hline \multirow{2}{*}{ Treatment } & \multicolumn{2}{|c|}{ Number of leaves per plant $\left(\mathrm{n}^{\circ}\right)$} \\
\hline & 14 dap & 42 dap \\
\hline \multicolumn{3}{|l|}{ Planting time } \\
\hline - Early planting-Pranoto Mongso & $10.00 \mathrm{a}$ & $49.76 \mathrm{a}$ \\
\hline - Middle planting-Farmer Method & $9.73 \mathrm{a}$ & $56.62 \mathrm{a}$ \\
\hline - Late planting-Katam Terpadu & $10.00 \mathrm{a}$ & $31.40 \mathrm{~b}$ \\
\hline \multicolumn{3}{|l|}{ Cultivar } \\
\hline - Anjasmoro & $13.18 \mathrm{a}$ & $75.03 \mathrm{a}$ \\
\hline - Grobogan & $11.50 \mathrm{~b}$ & $61.21 \mathrm{~b}$ \\
\hline - Argomulyo & $11.19 \mathrm{~b}$ & $63.69 \mathrm{~b}$ \\
\hline - Dega-1 & $10.30 \mathrm{c}$ & $53.23 \mathrm{c}$ \\
\hline Interaction & $(-)$ & $(-)$ \\
\hline \multicolumn{3}{|l|}{ Coefficient of variation (\%) } \\
\hline Planting time & 19.21 & 6.05 \\
\hline Cultivar & 1.17 & 19.85 \\
\hline
\end{tabular}

Note: (-) showing no interaction, meaning that it is followed by different letters and shows significant difference according to Duncan's Multiple Range Test at confidence level of 95\%. 
According to Table 2, there is an effect of interaction between planting time and soybean cultivars on number of leaves per plant at 28 and 56 dap. At early planting time-Pranoto Mongso, cultivar Anjasmoro had the highest number of leaves compared to other cultivars, while at middle planting time-Farmer Method, cultivar Dega-1 had the highest number of leaves compared to Argomulyo and Anjasmoro. At 56 dap, cultivar Anjasmoro produced a large number of leaves per plant when planted at late planting time-Katam Terpadu and at early planting timePranoto Mongso. Cultivar Dega-1 produced the highest number of leaves per plant when planted at middle planting time-Farmer Method. The late planting time-Katam Terpadu gave the same effects on the number of leaves per plant at 28 dap.

Table 2. Number of leaves per plant $\left(\mathrm{n}^{\circ}\right)$ of soybean cultivars at different planting times at 28 and 56 dap

\begin{tabular}{llcc}
\hline \multicolumn{1}{c}{ Treatment } & \multicolumn{1}{c}{ Cumber of leaves per plant $\left(\mathrm{n}^{\circ}\right)$} \\
\hline Planting time & \multicolumn{1}{c}{ Cultivar } & $28 \mathrm{dap}$ & $56 \mathrm{dap}$ \\
\hline Early planting-Pranoto Mongso & Anjasmoro & $35.57 \mathrm{a}$ & $83.64 \mathrm{a}$ \\
& Grobogan & $31.02 \mathrm{~b}$ & $64.30 \mathrm{~b}$ \\
& Argomulyo & $29.63 \mathrm{~b}$ & $68.93 \mathrm{~b}$ \\
& Dega-1 & $30.58 \mathrm{~b}$ & $58.57 \mathrm{~b}$ \\
Middle planting-Farmer Method & $24.40 \mathrm{~b}$ & $59.53 \mathrm{~b}$ \\
& Anjasmoro & $29.22 \mathrm{ab}$ & $56.33 \mathrm{~b}$ \\
& Grobogan & $26.33 \mathrm{~b}$ & $60.87 \mathrm{ab}$ \\
& Argomulyo & $33.53 \mathrm{a}$ & $69.60 \mathrm{a}$ \\
Late planting-Katam Terpadu & Dega-1 & $32.13 \mathrm{a}$ & $86.20 \mathrm{a}$ \\
& Anjasmoro & $27.67 \mathrm{a}$ & $64.14 \mathrm{bc}$ \\
& Grobogan & $28.87 \mathrm{a}$ & $78.08 \mathrm{ab}$ \\
& Argomulyo & $26.47 \mathrm{a}$ & $56.68 \mathrm{c}$ \\
\hline Interaction & Dega-1 & $(+)$ & $(+)$ \\
\hline Coefficient of variation (\%) & & & \\
Planting time & & 5.95 & 06.44 \\
Cultivar & & 8.79 & 16.46 \\
\hline
\end{tabular}

Note: (+) showing interaction, meaning that it is followed by different letters and shows significant difference according to Duncan's Multiple Range Test at confidence level of 95\%.

The optimal number of leaves allows the plant to carry out photosynthesis at the optimum level. Leaves are the primary organs of plants for the process of photosynthesis and transpiration, where the energy of light is held by leaf mesophyll cells and gas $\left(\mathrm{CO}_{2}, \mathrm{O}_{2}\right)$ and $\mathrm{H}_{2} \mathrm{O}$ are exchanged through leaf stomata (Tohari, 2017b). The stomata are composed of two guard cells that can control the opening and closing of leaf pores. Soybean plants have compound leaves shaped like hands and have stipules at the base of the stems. Soybean leaves have venation, which is part of the plant vascular system for water flow and nutrients (Sheaffer and Moncada, 2009).

\section{Total leaf area}

The leaf area is influenced by genotypes and environment. Leaf area supports plant growth, biomass production and vigor because of the photosynthesis which produces assimilates for plant life needs (Gardner et al., 1991). Assimilates are used by plants for cell division and enlargement so that the leaves expand. The increase in leaf area is affected by the lateral meristem located on the edge of the expanding young leaf. 
Table 3. Leaf area $\left(\mathrm{cm}^{2}\right)$ of soybean cultivars at different planting time

\begin{tabular}{|c|c|c|c|}
\hline \multirow{2}{*}{ Treatment } & \multicolumn{3}{|c|}{ Leaf area $\left(\mathrm{cm}^{2}\right)$} \\
\hline & 14 dap & 28 dap & 42 dap \\
\hline \multicolumn{4}{|l|}{ Planting time } \\
\hline -Early planting-Pranoto Mongso & $65.34 \mathrm{~b}$ & $428.18 \mathrm{~b}$ & $1340.51 \mathrm{a}$ \\
\hline -Middle planting-Farmer Method & $65.47 \mathrm{~b}$ & $543.22 \mathrm{a}$ & $1878.30 \mathrm{a}$ \\
\hline -Late planting-Katam Terpadu & $76.98 \mathrm{a}$ & $626.47 \mathrm{a}$ & $1350.60 \mathrm{a}$ \\
\hline \multicolumn{4}{|l|}{ Cultivar } \\
\hline -Anjasmoro & $59.03 \mathrm{~b}$ & $484.87 \mathrm{a}$ & $1310.31 \mathrm{a}$ \\
\hline -Grobogan & $78.89 \mathrm{a}$ & $581.23 \mathrm{a}$ & $1433.01 \mathrm{a}$ \\
\hline -Agromulyo & $71.15 \mathrm{a}$ & $536.17 \mathrm{a}$ & $1656.90 \mathrm{a}$ \\
\hline -Dega-1 & $68.00 \mathrm{ab}$ & $528.22 \mathrm{a}$ & $1692.20 \mathrm{a}$ \\
\hline Interaction & $(-)$ & $(-)$ & $(-)$ \\
\hline \multicolumn{4}{|l|}{ Coefficient of variation $(\%)$} \\
\hline Planting time & 07.14 & 5.59 & 2.73 \\
\hline Cultivar & 16.74 & 18.82 & 25.99 \\
\hline
\end{tabular}

Note: (-) showing no interaction, meaning that it is followed by different letters and shows significant difference according to Duncan's Multiple Range Test at confidence level of 95\%.

At 14 and 28 dap, soybean plants planted at late planting time-Katam Terpadu produced higher yields compared to those planted at other planting times (Table 3). However, at 28 dap, soybean plants planted at middle planting timeFarmer Method showed leaf area that increased rapidly so that the leaves observed also had wider size than leaf area of soybean plants planted at early planting time-Pranoto Mongso. At 42 dap, the development of the length and width of the leaves did not show any different response so that the resulting leaf area was relatively the same.

Table 4. Leaf area $\left(\mathrm{cm}^{2}\right)$ of soybean cultivars at different planting time at 56 dap

\begin{tabular}{|c|c|c|}
\hline \multicolumn{2}{|c|}{ Treatment } & \multirow{2}{*}{ Leaf area $\left(\mathrm{cm}^{2}\right)$} \\
\hline Planting time & Cultivar & \\
\hline \multirow[t]{4}{*}{ Early planting-Pranoto Mongso } & Anjasmoro & $3,146.5 \mathrm{a}$ \\
\hline & Grobogan & $1,900.0 \mathrm{~b}$ \\
\hline & Argomulyo & $2,566.3 \mathrm{ab}$ \\
\hline & Dega-1 & $1,707.2 \mathrm{~b}$ \\
\hline \multirow[t]{4}{*}{ Middle planting-Farmer Method } & Anjasmoro & $2,675.6 \mathrm{ab}$ \\
\hline & Grobogan & $1,799.3 \mathrm{~b}$ \\
\hline & Argomulyo & $3,434.6 \mathrm{a}$ \\
\hline & Dega-1 & $2,642.5 \mathrm{ab}$ \\
\hline \multirow[t]{4}{*}{ Late planting-Katam Terpadu } & Anjasmoro & $1,796.3 \mathrm{a}$ \\
\hline & Grobogan & $1,878.5 \mathrm{a}$ \\
\hline & Argomulyo & $1,774.4 \mathrm{a}$ \\
\hline & Dega-1 & $1,807.3 \mathrm{a}$ \\
\hline \multicolumn{2}{|c|}{ Interaction } & $(+)$ \\
\hline \multicolumn{3}{|l|}{ Coefficient of variation (\%) } \\
\hline \multicolumn{2}{|l|}{ Planting time } & 07.74 \\
\hline \multicolumn{2}{|l|}{ Cultivar } & 23.44 \\
\hline
\end{tabular}

Note: (+) showing interaction, meaning that it is followed by different letters and shows significant difference according to Duncan's Multiple Range Test at confidence level of 95\%.

Leaf area of soybean cultivars at 56 dap was influenced by planting time. At late planting timeKatam Terpadu, all soybean cultivars had the same leaf area, but at early planting time-Pranoto Mongso, cultivar Anjasmoro had wider leaf area compared to Grobogan and Dega-1. Meanwhile, at middle planting time-Farmer Method, cultivar Argomulyo had wider leaf area compared to Grobogan. The development of leaf area is supported by the ability of soybeans to provide 
nitrogenous nutrients through $\mathrm{N}_{2}$ fixation in the air by soybean root nodules (Vitousex et al., 2002).

In this study, the plants treated with early planting time-Pranoto Mongso and middle planting time-Farmer Method during vegetative growth 1 and 2 experienced drought conditions, which reduced the moisture content of the soil up to below the permanent wilting point, occurring briefly for 24 hours. This condition is possible to influence differences in leaf area of plants on cultivars planted at 14 dap, in which Grobogan and Argomulyo cultivars had the highest leaf area. Sufficient water supports an increase in leaf area, while a decrease in leaf area is the plant's first response to drought. Soybean cultivars that are resistant to drought can maintain a greater leaf area during stress periods (Oya et al., 2004). Grobogan and Argomulyo cultivars are drought resistant cultivars (BALITKABI, 2016). Plants that have the widest leaf area at the beginning of growth will grow and develop faster because they have higher photosynthates. Drought stress occurring briefly does not cause plants to experience a negative impact, which is proven by plants which were able to grow and develop optimally at 56 dap. Drought stress that continues for a long time can cause a decrease in the rate of photosynthesis and a negative impact on plants
(Gardner et al., 1991). All cultivars planted at late planting time-Katam Terpadu had the same leaf area because drought did not occur during vegetative and generative growth.

Anjasmoro and Argomulyo cultivars produced leaves with wider total leaf area on average (Table 4) but produced lower seed yields compared to Grobogan and Dega-1 cultivars (Table 6). Leaf area and leaf shape are associated with morphological characters that influence soybean yield. Genetically, broadleaf soybean plants tend to produce lower number of seeds while smalland-pointed-leaf soybean plants tend to yield a higher number of seeds (Jeong et al., 2012).

\section{Specific leaf area}

Specific leaf area (SLA) is defined as the efficiency of the formation of leaf area per unit of carbohydrate available. At 14, 28 and 56 dap, the treatment of late planting time-Katam Terpadu produced the highest leaf area compared to other treatments, while at 42 dap, the different planting time did not give any significant effect. Leaf areas of all cultivars at 14 and 28 dap were not significantly different. Cultivar Dega- 1 had the highest SLA at 42 dap, while cultivar Anjasmoro had the SLA at 56 dap (Table 5).

$\underline{\text { Table 5. SLA }\left(\mathrm{cm}^{2} \mathrm{~g}^{-1}\right) \text { of soybean cultivars at different planting time }}$

\begin{tabular}{|c|c|c|c|c|}
\hline \multirow{2}{*}{ Treatment } & \multicolumn{4}{|c|}{ SLA $\left(\mathrm{cm}^{2} \mathrm{~g}^{-1}\right)$} \\
\hline & 14 dap & 28 dap & 42 dap & 56 dap \\
\hline \multicolumn{5}{|l|}{ Planting time } \\
\hline -Early planting-Pranoto Mongso & $279.49 \mathrm{~b}$ & $355.92 \mathrm{~b}$ & $332.85 \mathrm{a}$ & $304.93 \mathrm{~b}$ \\
\hline -Middle planting-Farmer Method & $310.65 \mathrm{ab}$ & $370.67 \mathrm{~b}$ & $321.63 \mathrm{a}$ & $324.90 \mathrm{~b}$ \\
\hline -Late planting-Katam Terpadu & $327.61 \mathrm{a}$ & $481.82 \mathrm{a}$ & $407.32 \mathrm{a}$ & $425.35 \mathrm{a}$ \\
\hline \multicolumn{5}{|l|}{ Cultivar } \\
\hline -Anjasmoro & $290.22 \mathrm{a}$ & $401.65 \mathrm{a}$ & $286.23 \mathrm{~b}$ & $428.67 \mathrm{a}$ \\
\hline -Grobogan & $312.90 \mathrm{a}$ & $405.43 \mathrm{a}$ & $320.14 \mathrm{ab}$ & $266.77 \mathrm{~b}$ \\
\hline -Argomulyo & $329.05 \mathrm{a}$ & $401.29 \mathrm{a}$ & $382.24 \mathrm{ab}$ & $382.74 \mathrm{a}$ \\
\hline -Dega-1 & $291.50 \mathrm{a}$ & $402.84 \mathrm{a}$ & $427.12 \mathrm{a}$ & $328.72 \mathrm{ab}$ \\
\hline Interaction & $(-)$ & $(-)$ & $(-)$ & $(-)$ \\
\hline \multicolumn{5}{|l|}{ Coefficient of variation (\%) } \\
\hline Planting time & 9.49 & 6.38 & 3.13 & 5.19 \\
\hline Cultivar & 13.67 & 18.92 & 29.11 & 28.93 \\
\hline
\end{tabular}

Note: (-) showing no interaction, meaning that it is followed by different letters and shows significant difference according to Duncan's Multiple Range Test at confidence level of 95\%.

\section{Specific leaf weight}

Specific leaf weight (SLW) is an indicator of plant leaf thickness where the higher the SLW value is, the thicker the leaves will be. Thick leaves will have higher number of cells than thin leaves.

SLW of soybean cultivars at 14, 28, 42 and 56 dap is presented in Table 6 . At 14 and 28 days, soybean plants planted at early planting time- 
Pranoto Mongso produced the highest SLW compared to those planted at late planting timeKatam Terpadu. At 42 dap, soybean plants planted at middle planting time-Farmer Method had higher SLW compared to those planted at late planting time-Katam Terpadu, while at 56 dap, the treatment of planting time did not put any significant effect on SLA. Meanwhile, among all cultivars, Anjasmoro had the highest SLA at 14 and 42 dap. However, at 28 dap, there was no significant difference of SA width among cultivars. At 56 days, cultivar Grobogan had the highest SLW compared to those at other treatments, although it was not significantly different from Dega-1.

Table 6. SLW $\left(\mathrm{g} \mathrm{cm}^{2-1}\right)$ of soybean cultivars at different planting time

\begin{tabular}{llccc}
\hline \multirow{2}{*}{ Treatment } & \multicolumn{4}{c}{ SLW $\left(\mathrm{g} \mathrm{cm}^{2-1}\right)$} \\
\cline { 2 - 5 } & $14 \mathrm{dap}$ & $28 \mathrm{dap}$ & $42 \mathrm{dap}$ & 56 dap \\
\hline Planting time & & & & \\
-Early planting-Pranoto Mongso & $37.10^{-4} \mathrm{a}$ & $30.10^{-4} \mathrm{a}$ & $32.10^{-4} \mathrm{ab}$ & $35.10^{-4} \mathrm{a}$ \\
-Middle planting-Farmer Method & $33.10^{-4} \mathrm{ab}$ & $28.10^{-4} \mathrm{a}$ & $35.10^{-4} \mathrm{a}$ & $36.10^{-4} \mathrm{a}$ \\
-Late planting-Katam Terpadu & $31.10^{-4} \mathrm{~b}$ & $21.10^{-4} \mathrm{~b}$ & $27.10^{-4} \mathrm{~b}$ & $26.10^{-4} \mathrm{a}$ \\
Cultivar & & & & \\
-Anjasmoro & $36.10^{-4} \mathrm{a}$ & $27.10^{-4} \mathrm{a}$ & $36.10^{-4} \mathrm{a}$ & $27.10^{-4} \mathrm{~b}$ \\
-Grobogan & $33.10^{-4} \mathrm{ab}$ & $25.10^{-4} \mathrm{a}$ & $35.10^{-4} \mathrm{ab}$ & $40.10^{-4} \mathrm{a}$ \\
-Argomulyo & $31.10^{-4} \mathrm{~b}$ & $26.10^{-4} \mathrm{a}$ & $28.10^{-4} \mathrm{bc}$ & $28.10^{-4} \mathrm{~b}$ \\
-Dega-1 Interaction & $35.10^{-4} \mathrm{a}$ & $26.10^{-4} \mathrm{a}$ & $26.10^{-4} \mathrm{c}$ & $33.10^{-4} \mathrm{ab}$ \\
\hline \multicolumn{1}{c}{$(-)$} & $(-)$ & $(-)$ & $(-)$ \\
\hline Coefficient of variation $(\%)$ & & & & \\
Planting time & 08.27 & 06.97 & 05.00 & 03.82 \\
Cultivar & 15.12 & 22.38 & 24.46 & 33.61 \\
\hline
\end{tabular}

Note: (-) showing no interaction, meaning that it is followed by different letters and shows significant difference according to Duncan's Multiple Range Test at confidence level of $95 \%$.

Thickening of leaves is one of plant responses to water shortages (Nio and Yunia, 2011). In conditions of sufficient water availability, Grobogan and Dega-1 cultivars have high leaf thickness so that they have many leaf cells which allow maximum photosynthesis. Leaves that are not shaded can absorb maximum sunlight so that the NAR increases (Putra, 2015).

Leaf area index (LAI), net assimilation rate (NAR) and crop growth rate (CGR)

Growth analysis is used as one of the approaches to analyze the factors that influence plant growth and yield in a form of assimilate accumulation at a certain time. The increase in assimilate yield per unit time can be seen from the variable of NAR and CGR. NAR is influenced by several factors, including the availability of water, light, temperature, carbon dioxide, age of leaves, nutrition, leaf chlorophyll content and genotype
(Stoskopf, 1981). NAR is a measure of the average photosynthetic efficiency of leaves in a crop community (Gardner et al., 1991).

According to the analysis of the growth of soybean plants at 4 weeks after planting (wap), there were different responses to the treatment of planting time. Soybean plants planted at late planting time-Katam Terpadu and middle planting time-Farmer Method had a higher LAI compared to those planted at early planting timePranoto Mongso. High LAI of plants planted at middle planting time-Farmer Method, will increase NAR, compared to those of plants cultivated at late planting time-Katam Terpadu. High NAR then will increase CGR. At 8 wap, the planting time and cultivars did not give any significant effects on NAR. Growth analysis in all four soybean cultivars did not show any different response, meaning that all cultivars planted had uniform LAI, NAR and CGR (Table 7). 
Table 7. LAI at 4 wap, NAR $\left(\mathrm{g} \mathrm{cm}^{-2}\right.$ week $\left.{ }^{-1}\right)$ at 4 and 8 wap and CGR $\left(\mathrm{g} \mathrm{cm}^{-2}\right.$ week $\left.{ }^{-1}\right)$ at 4 wap

\begin{tabular}{lcccc}
\hline \multicolumn{1}{c}{ Treatment } & LAI & NAR at 4 wap & NAR at 8 wap & CGR at 4 wap \\
\hline Planting time & & & & \\
-Early planting-Pranoto Mongso & $0.54 \mathrm{~b}$ & $70.10^{-5} \mathrm{a}$ & $46.10^{-5} \mathrm{a}$ & $17.10^{-5} \mathrm{~b}$ \\
-Middle planting-Farmer Method & $0.68 \mathrm{a}$ & $77.10^{-5} \mathrm{a}$ & $34.10^{-5} \mathrm{a}$ & $21.10^{-5} \mathrm{a}$ \\
-Late planting-Katam Terpadu & $0.78 \mathrm{a}$ & $56.10^{-5} \mathrm{~b}$ & $25.10^{-5} \mathrm{a}$ & $19.10^{-5} \mathrm{ab}$ \\
Cultivar & & & & \\
-Anjasmoro & $0.61 \mathrm{a}$ & $73.10^{-5} \mathrm{a}$ & $32.10^{-5} \mathrm{a}$ & $18.10^{-5} \mathrm{a}$ \\
-Grobogan & $0.73 \mathrm{a}$ & $63.10^{-5} \mathrm{a}$ & $38.10^{-5} \mathrm{a}$ & $20.10^{-5} \mathrm{a}$ \\
-Argomulyo & $0.67 \mathrm{a}$ & $68.10^{-5} \mathrm{a}$ & $37.10^{-5} \mathrm{a}$ & $19.10^{-5} \mathrm{a}$ \\
-Dega-1 Interaction & $0.66 \mathrm{a}$ & $68.10^{-5} \mathrm{a}$ & $33.10^{-5} \mathrm{a}$ & $19.10^{-5} \mathrm{a}$ \\
\hline \multicolumn{1}{c}{$(-)$} & $(-)$ & $(-)$ & $(-)$ \\
\hline Coefficient of variation (\%) & $(-)$ & & \\
Planting time & 05.63 & 10.06 & 01.26 & 07.11 \\
Cultivar & 18.82 & 21.34 & 65.42 & 23.31 \\
\hline
\end{tabular}

Note: (-) showing no interaction, meaning that it is followed by different letters and shows significant difference according to Duncan's Multiple Range Test at confidence level of 95\%.

When the age of plant increases, NAR tends to decrease. This can be seen at 4 and 8 wap. Decrease in NAR is influenced by total leaf area and SLA of plants. Leaves that actively carry out photosynthesis affect NAR of plants, while unproductive leaves such as old or shaded leaves will reduce the NAR. The growth of the crops is characterized by the increasing LAI resulting in more leaves protected so as to reduce NAR throughout the growing season (Gardner et al., 1991). In plant canopies that have high LAI, young leaves can absorb the most solar radiation, have the highest rate of $\mathrm{CO}_{2}$ assimilation and translate most of the assimilates to plant parts. Old leaves on a canopy and protected base have low $\mathrm{CO}_{2}$ assimilation rate and this gives a small amount of assimilate to plant parts. Plants that are in ideal environmental conditions put effect on increasing leaf area which affects LAI and maximum light absorption (Alam, 2015; Su et al., 2015).

Table 8. LAI at 8 wap and CGR $\left(\mathrm{g} \mathrm{cm}^{-2}\right.$ week $\left.^{-1}\right)$ at 8 wap

\begin{tabular}{|c|c|c|c|}
\hline \multicolumn{2}{|l|}{ Treatment } & \multirow{2}{*}{ LAI } & \multirow{2}{*}{ CGR* } \\
\hline Planting time & Cultivar & & \\
\hline \multirow{4}{*}{ Early planting-Pranoto Mongso } & Anjasmoro & $3.93 \mathrm{a}$ & $25.10^{-3} \mathrm{a}$ \\
\hline & Grobogan & $2.16 \mathrm{~b}$ & $22.10^{-3} \mathrm{a}$ \\
\hline & Argomulyo & $3.21 \mathrm{ab}$ & $22.10^{-3} \mathrm{a}$ \\
\hline & Dega-1 & $2.13 \mathrm{~b}$ & $12.10^{-3} \mathrm{a}$ \\
\hline \multirow[t]{4}{*}{ Middle planting-Farmer Method } & Anjasmoro & $3.34 \mathrm{ab}$ & $24.10^{-3} \mathrm{ab}$ \\
\hline & Grobogan & $2.20 \mathrm{~b}$ & $62.10^{-4} \mathrm{~b}$ \\
\hline & Argomulyo & $4.29 \mathrm{a}$ & $29.10^{-3} \mathrm{a}$ \\
\hline & Dega-1 & $3.26 \mathrm{ab}$ & $19.10^{-3} \mathrm{ab}$ \\
\hline \multirow[t]{4}{*}{ Late planting-Katam Terpadu } & Anjasmoro & $2.25 \mathrm{a}$ & $14.10^{-4} \mathrm{~b}$ \\
\hline & Grobogan & $2.35 \mathrm{a}$ & $18.10^{-3} \mathrm{a}$ \\
\hline & Argomulyo & $2.18 \mathrm{a}$ & $76.10^{-4} \mathrm{ab}$ \\
\hline & Dega-1 & $2.26 \mathrm{a}$ & $15.10^{-3} \mathrm{a}$ \\
\hline Interaction & & $(+)$ & $(+)$ \\
\hline \multicolumn{2}{|l|}{ Coefficient of variation $(\%)$} & & \\
\hline \multicolumn{2}{|l|}{ Planting time } & 07.45 & 3.58 \\
\hline \multicolumn{2}{|l|}{ Cultivar } & 23.38 & 30.86 \\
\hline
\end{tabular}

Note: (-) showing no interaction, meaning that it is followed by different letters and shows significant difference according to Duncan's Multiple Range Test at confidence level of $95 \%$ *Data were transformed to $\sqrt{X}$ 
The ability of leaves to photosynthesize is limited by leaf area and small-leaf period, low chlorophyll content and low leaf protein. Low photosynthesis rate leads to low NAR and CGR because the accumulation of dry matter of plants as a net result of photosynthesis is reduced which ultimately decreases the dry weight of plants (Sabban, 2012).

Soybean cultivars planted at late planting time-Katam Terpadu did not show different LAI and CGR. Planted at early planting-Pranoto Mongso, cultivar Anjasmoro had higher LAI compared to Grobogan and Dega-1. On the contratry, planted at middle planting time-Farmer Method, cultivar Argomulyo had the highest LAI. LAI can affect CGR value. When planted at late planting time-Katam Terpadu, cultivar Grobogan and Dega-1 had higher CGR compared to Anjasmoro. Meanwhile when planted at middle planting time-Farmer Method, cultivar Argomulyo had higher yield compared to Grobogan. During the phase of seed filling to physiological maturity, LAI values range from 46 (Leopard and Kriedemann, 1975). LAI values are influenced by plant leaf area, environmental conditions and solar radiation. Wider leaf area will lead to higher LAI values (Putra, 2015). At maximum LAI, soybean leaves carry out maximum net photosynthesis requiring saturated light between 0.27-2.17 $\mathrm{cal} \mathrm{cm}^{-2}$ minutes ${ }^{-1}$ with photosynthetis rate of 8-65 $\mathrm{mg} \mathrm{CO}_{2} \mathrm{dm}^{-2}$ hours $^{-1}$ (Beuerlein and Pendleton, 1971). This shows that LAI directly relates to plant dry weight due to increasing plant photosynthesis rates (Table 8).

\section{Plant dry weight and seed yield per plant}

The dry weight of plants at 14 dap did not show any significant differences at different planting times, but the treatment of planting time gave significant effect at 28, 42 and 56 dap. At 28, 42 and 56 dap, soybean plants planted at middle planting time-Farmer Method had the highest dry weight of plants compared to other planting time. At 28 dap, the soybean plants planted at middle planting time-Farmer Method could accumulate the most assimilates characterized by the highest dry weight of the plant compared to those planted at early planting time-Pranoto Mongso. At 42 dap, the plants planted at middle planting timeFarmer Method showed higher dry weight compared to those planted at late planting timeKatam Terpadu. Meanwhile at 56 dap, the plants planted at early planting time-Pranoto Mongso and middle planting time-Farmer Method accumulated higher assimilates compared to those planted at late planting time-Katam Terpadu (Table 9).

Table 9. Plant dry weight $(\mathrm{g})$ and seed yield per plant $(\mathrm{g})$

\begin{tabular}{lccccc}
\hline \multirow{2}{*}{ Treatment } & \multicolumn{4}{c}{ Plant dry weight $(\mathrm{g})$} & \multirow{2}{*}{$\begin{array}{c}\text { Seed yield } \\
\text { per plant }(\mathrm{g})\end{array}$} \\
\cline { 2 - 5 } & $14 \mathrm{dap}$ & $28 \mathrm{dap}$ & $42 \mathrm{dap}$ & $56 \mathrm{dap}$ & \\
Planting time & & & & & \\
-Early planting-Pranoto Mongso & $0.37 \mathrm{a}$ & $2.26 \mathrm{~b}$ & $9.26 \mathrm{ab}$ & $20.11 \mathrm{a}$ & $29.11 \mathrm{a}$ \\
-Middle planting-Farmer Method & $0.34 \mathrm{a}$ & $2.72 \mathrm{a}$ & $13.80 \mathrm{a}$ & $24.21 \mathrm{a}$ & $26.75 \mathrm{a}$ \\
-Late planting-Katam Terpadu & $0.38 \mathrm{a}$ & $2.45 \mathrm{ab}$ & $7.46 \mathrm{~b}$ & $13.07 \mathrm{~b}$ & $20.30 \mathrm{~b}$ \\
Cultivar & & & & & \\
-Anjasmoro & $0.32 \mathrm{~b}$ & $2.30 \mathrm{a}$ & $10.19 \mathrm{a}$ & $19.10 \mathrm{a}$ & $19.79 \mathrm{c}$ \\
-Grobogan & $0.41 \mathrm{a}$ & $2.65 \mathrm{a}$ & $11.10 \mathrm{a}$ & $19.29 \mathrm{a}$ & $28.39 \mathrm{a}$ \\
-Argomulyo & $0.35 \mathrm{~b}$ & $2.49 \mathrm{a}$ & $9.80 \mathrm{a}$ & $20.22 \mathrm{a}$ & $23.25 \mathrm{~b}$ \\
-Dega-1 & $0.37 \mathrm{ab}$ & $2.47 \mathrm{a}$ & $9.59 \mathrm{a}$ & $17.91 \mathrm{a}$ & $30.11 \mathrm{a}$ \\
\hline \multicolumn{1}{c}{ Interaction } & $(-)$ & $(-)$ & $(-)$ & $(-)$ & $(-)$ \\
\hline Coefficient $\%)$ & 5.67 & 8.05 & 2.17 & 4.98 & 9.63 \\
Planting time & 14.27 & 19.41 & 24.9 & 24.23 & 10.21 \\
Cultivar & & & & & \\
\hline
\end{tabular}

Note: (-) showing no interaction, meaning that it is followed by different letters and shows significant difference according to Duncan's Multiple Range Test at confidence level of 95\%

The initial growth of plant is exponential which is described by the relative growth rate based on the rate of dry weight increase in relation to the dry weight of the whole parts of the plant. The dry weight of plants illustrates the accumulation of assimilates carried out through 
photosynthesis during plant growth and development before harvest. Plant destructive growth can be observed from the accumulation of photosynthates in dry weight. The soybean cultivars tested showed different responses in accumulating the assimilates produced from photosynthesis only at 14 dap, in which cultivar Grobogan had higher plant dry weight compared to Anjasmoro and Argomulyo. Meanhile at 28, 42 and 56 dap, the accumulation of photosynthates used for growth in plants did not indicate different results. Increasing plant dry weight confirms that photosynthesis works well resulting in assimilation to form maximum biomass (Zelalem et al., 2009). The total dry weight of crop is a result of the accumulation of net $\mathrm{CO}_{2}$ assimilation throughout the growth season since assimilation of $\mathrm{CO}_{2}$ is the result of absorption of solar energy. High biomass encourages an increase in the number of pods and seeds (Liu et al., 2005).

There is a relationship between LAI and dry matter production that follows an asymptotic curve. On this curve, it is seen that during the production of dry matter, the soybean plant is not at LAI levels greater than the need for full radiation interception, and thus the lower leaves protected by the canopy do not harm the productive part (Shibles and Weber, 1965). Increased yields are supported by increasing source production due to increasing $\mathrm{CO}_{2}$ fixation (Tekalign and Hammes, 2005). Photosynthesis produces dry matter from parts of plants in the amount of $90-95 \%$. Photosynthesis is the capture of energy derived from sunlight by chlorophyll for the formation of organic matter (Da-yong et al., 2012).

Dega-1 and Grobogan cultivars had higher seed yield per plant than Anjasmoro and Argomulyo. Meanwhile, soybean plants planted at early planting time-Pranoto Mongso and middle planting time-Farmer Method produced higher seed yield per plant compared to those planted at late planting time-Katam Terpadu. The high dry weight of plants at 56 dap contributed to high seed yield per plant observed on the plants planted at early planting time-Pranoto Mongso and middle planting time-Farmer Method. Early planting has a small risk of competition compared to late planting. This competition includes the availability of water that affects soil moisture content, humidity, temperature, sunlight and carbon dioxide (Tohari, 2017a), and thus affects the high seed yield per plant.

\section{CONCLUSIONS}

This study concudes that the treatment of planting time and cultivar increases leaf physiological activity, particularly the number of leaves, total leaf area, LAI and plant growth rate. Early planting time-Pranoto Mongso and middle planting time-Farmers Method produced the highest plant dry weight $(20.11 \mathrm{~g} ; 24.21 \mathrm{~g})$ and seed yields per plant $(29.11 \mathrm{~g} ; 26.75 \mathrm{~g})$ than late planting-Katam Terpadu (20.30 g). Meanwhile, cultivar Dega-1 had higher seed yields per plant $(30.11 \mathrm{~g})$ than cultivar Grobogan (28.39 g), Argomulyo (23.35 g) and Anjasmoro (19.79 g).

\section{REFERENCES}

Alam, T. (2015). Optimasi Pengeloaan Sistem Agroforestri Cengkeh, Kakao, Kapulaga di Pegunungan Menoreh.(Thesis). Universitas Gadjah Mada Yogyakarta.

BALITKABI. (2016). Deskripsi Varietas Unggul Kacang-kacangan dan Umbi-umbian. Balai Penelitian Tanaman Aneka Kacang dan Umbi. Badan Penelitian dan Pengembangan Pertanian, Kementerian Pertanian.

Beuerlein, J. E., \& Pendleton, J. W. (1971). Photosynthetic rates and light saturation curves of individual Soybean leaves under field condition. Crop Science, 11 (2), 217-219. https://doi.org/doi:10.2135/cropsci1971.0011 183X001100020015x

Blum, A. (2005). Drought resistance, water-use efficiency, and yield potential_Are they compatible, dissonant, or mutually exclusive? Australian Journal of Agricultural Research, 56(11), 1159-1168. https://doi.org/doi: 10.1071/ar05069

Boote, J.R., Stansell, A.M., S. \& J. F. S. (1982). Irrigation, water use and water relations. In: H.E. Patte \& C.T Young (Eds.) Peanut Science and Technology. APPRES. Texas. USA.

Budiasa, I. W. (2011). Pertanian berkelanjutan: Teori dan Pemodelan. Denpasar: Udayana University Press.

Clarke, J. M. (1986). Effect Of Leaf Rolling On Leaf Water Loss In Triticum spp. Can. J. Plant Sci. 66(4), 885-891. https://doi.org/doi: 10.4141/cjps86-111

Da-Yong, L., Zhi-an, Z., Dian-jun, Z., Li-yan, J., 
\& Yuan-li, W. (2012). Comparison of Net Photosynthetic Rate in Leaves of Soybean with Different Yield Levels. Journal of Northeast Agricultural University, 19(3), 1419. https://doi.org/10.1016/S1006-8104(13) 60017-3

Devi, J. M., Sinclair, T. R., Chen, P., \& Carter, T. E. (2014). Evaluation of Elite Southern Maturity Soybean Breeding Lines for Drought-Tolerant Traits. Agron. J., 106(6), 1947-1954. https://doi.org/10.2134/agronj 14.0242

Doorenbos, J., \& Kassam, A. (1979). Yield Response to Water FAO Irrigation and Drainage. Paper No. 33. FAO, Rome.

Fagi, A. M., \& Tangkuman, F. (1985). Pengelolaan air untuk kedelai. Pusat Penelitian dan Pengembangan Tanaman Pangan. Retrieved from Badan Penelitian dan Pengembangan Pertanian. Bogor.

Gardner, F. P., Pearce, R. B., \& Mitchell, R. L. (1991). Physiology of Crop Plant (Fisiologi Tanaman Budidaya, alih bahasa: H. Susilo). UI-Press. Jakarta.

Gilbert, M. E., Holbrook, N. M., Zwieniecki, M. A., Sadok, W., \& Sinclair, T. R. (2011). Field confirmation of genetic variation in soybean transpiration response to vapor pressure deficit and photosynthetic compensation. Field Crops Research, 124(1), 85-92. https://doi.org/ 10.1016/j.fcr.2011.06.011

Goodger, J. Q. D., \& Schachtman, D. P. (2015). Re-examining the role of $\mathrm{ABA}$ as the primary long-distance signal produced by waterstressed roots. Plant Signaling and Behaviour, 5(10), 1298-1301. https://doi.org/10.4161/ psb.5.10.13101

Jeong, N., Suh, S. J., Kim, M., Lee, S., Moon, J., Kim, H. S., \& Jeong, S. (2012). Ln Is a Key Regulator of Lea fl et Shape and Number of Seeds per Pod in Soybean. The Plant Cell, 24(12), 4807-4818. https://doi.org/10.1105 /tpc.112.104968

Jha, P. K., Kumar, S. N., \& Ines, A. V. M. (2018). Responses of soybean to water stress and supplemental irrigation in upper IndoGangetic plain: Field experiment and modeling approach. Field Crops Research, 219(15), 76-86. https://doi.org/10.1016/j.fcr.

\subsubsection{9}

Kholova, M. J. (2010). Understanding of terminal Drougt Tolerance Mechanisms in Perarl Millet (Pennissetum glaucum (L) R. Br.). Faculty of Science. Charles University in Prague. The Chech Republic.

Lehmann, N., Finger, R., Klein, T., Calanca, P., \& Walter, A. (2013). Adapting crop management practices to climate change : Modeling optimal solutions at the field scale. Agricultural Systems, 117, 55-65. https://doi.org/10.1016/ j.agsy.2012.12.011

Leopard A. C., \& Kriedemann. (1975). Plant Growth and Development. Tata Mc. Grow Hill Pub.Co.Ltd., New Delhi.

Levitt, J. (1980). Responses of Plant to Environmental Stress. Volume II. Second Edition. Academic Press. New York.

Liu, X., Jin, J., Herbert, S. J., Zhang, Q., \& Wang, G. (2005). Yield components, dry matter, LAI and LAD of soybeans in Northeast China. Field Crops Research, 93(1), 85-93. https://doi.org/10.1016/j.fcr.2004.09.005

Ludwig, F., Biemans, H., Jacobs, C., Supit, I., Van Diepen, C. A., Fawell, J., Capri, E. \& Steduto, P. (2011). Water Use of Oil Crops: Current Water Use and Future Outlooks. ILSI Europe aisbl.

Manavalan, L. P., Guttikonda, S. K., Phan Tran, L.-S., \& Nguyen, H. T. (2009). Physiological and Molecular Approaches to Improve Drought Resistance in Soybean. Plant and Cell Physiology, 50(7), 1260-1276. https://doi.org/ $10.1093 / \mathrm{pcp} / \mathrm{pcp} 082$

Nio, S. A., \& Yunia, B. (2011). Konsentrasi Klorofil Daun Sebagai Indikator Kekurangan Air pada Tanaman. Jurnal Ilmiah Sains, 2, 167-173. Retrieved from https://ejournal. unsrat.ac.id/index.php/JIS/article/view/202

Nugrahaeni, N., Sundari, T., \& Santoso, G. A. (2012). Hasil dan Komponen Hasil Galurgalur Kedelai Berumur Genjah di Lahan Kering Masam Lampung. In Seminar Nasional Hasil Penelitian Tanaman Aneka Kacang dan Umbi 15 November 2011 (p. 11). Balai Penelitian Tanaman Aneka Kacang dan Umbi (Balitkabi) Malang, Pusat Penelitian dan Pengembangan Tanaman Pangan. 
Nurhayati. (2010). Analisis karakteristik iklim untuk optimalisasi produksi kedelai di Propinsi Lampung, Laporan akhir program insentif PKPP Ristek 2010. Jakarta.

Oya, T., Nepomuceno, A. L., Neumaier, N., Renato, J., Farias, B., Tobita, S., \& Ito, O. (2004). Drought Tolerance Characteristics of Brazilian Soybean Cultivars - Evaluation and characterization of drought tolerance of various Brazilian soybean cultivars in the field - Drought Tolerance Characteristics of Brazilian Soybean Cultivars ź Evaluation and. Plant Production Science, 7(2), 129-137. https://doi.org/10.1626/pps.7.129

Purwanto, \& Cahyono, S. A. (2012). Identifikasi Kerentanan Sosial Ekonomi kelembagaan untuk Pengelolaan DAS Tulis (Dataran Tinggi Dieng). In Prosiding Seminar Nasional Pengeloaan Sumberdaya Alam dan Lingkungan. Semarang, 11 September 2012.

PUSDATIN KEMENTAN. (2016). Outlook Komoditas Pertanian Sub Sektor Tanaman Pangan Kedelai. Pusat Data dan Sistem Informasi Pertanian Kementerian Pertanian.

Putra, F. P. (2015). Pertumbuhan dan Hasil Tanaman serta Komposisi Gulma di berbagai Proporsi Populasi Pada Sistem Tumpangsari Padi Gogo + Kedelai di Lahan Pasir Pantai. (Thesis). Universitas Gadjah Mada.

Reijntjes, C., Haverkort, B., \& WatersBayer, A. (1999). Pertanian Masa Depan Pengantar Untuk Pertanian Berkelanjutan dengan Input Luar Rendah (Terjemahan Bahasa Indonesia oleh Y. Sukoco). Penerbit Mitra Tani, ILEIA dan Kanisius.

Sabban, H. (2012). Pengaruh Pengurangan Anak Daun terhadap karakter Fisiologis, Pertumbuhan dan Hasil beberapa varietas Kedelai. (Thesis). Universitas Gadjah Mada.

Saruhan, N., Terzi, R., Saglam, A., \& Kadioglu, A. (2009). The Relationship between Leaf Rolling and Ascorbate-Glutathione Cycle Enzymes in Apoplastic and Symplastic Areas of Ctenanthe setosa Subjected to Drought Stress. Biological Research, 42(3), 315-326. Retrieved from https://www.ncbi.nlm.nih.gov/ pubmed/19915740

SAS Institute Inc. (1985). SAS User's Guides: statistic, version 5 edition. Cary, NC: SAS
Institute Inc.

Sentelhas, P. C., Battisti, R., Câmara, G. M. S., Farias, J. R. B., \& Hampf, A. C. (2015). The soybean yield gap in Brazil - magnitude, causes and possible solutions for sustainable production. J. Agric. Sci., 153(8), 1394-1411. https://doi.org/10.1017/S0021859615000313

Sheaffer, C. C., \& Moncada, K. M. (2009). Introduction to Agronomy: Food, Crops and Environment. Canada: Nelson Education, Ltd.

Shibles, R. M., \& Weber, C. R. (1965). Leaf area, solar radiation, interception and dry matter production by soybeans. Crop Sci., 5, 575578. Retrieved from https://dl. sciencesocieties.org/publications/cs/abstracts/ 5/6/CS0050060575 access $=0 \&$ view $=p d f$

Stoskopf, N. (1981). Understanding Crop Production. Reston Publishing Company. Inc. Virginia.

Su, L., Wang, Q., Wang, C., \& Shan, Y. (2015). Simulation Models of Leaf Area Index and Yield for Cotton Grown with Different Soil Conditioners. PLOS ONE, 10(11), 1-19. https://doi.org/10.1371/journal.pone.0141835

Sudarsono, \& Widoretno, W. (2003). Pengaruh Cekaman Kekeringan Pada Fase Pertumbuhan Generatif Terhadap Pertumbuhan dan Hasil Kedelai Yang Berbeda Toleransinya Terhadap Stres. Jurnal Penelitian Pertanian., 22(2).

Tekalign, T., \& Hammes, P. S. (2005). Growth and productivity of potato as influenced by cultivar and reproductive growth II. Growth analysis, tuber yield and quality. Scientia Horticulturae, 105, 29-44. https://doi.org/ 10.1016/j.scienta.2005.01.021

Tohari. (2017a). Geometri dan Sistem Pertanaman. In Tohari (Ed.), Aspek Dasar Agronomi Berkelanjutan (Cetakan Pe, pp. 199-245). Yogyakarta: Gadjah Mada University Press.

Tohari. (2017b). Tanaman:Transformer Energi Matahari. In Tohari (Ed.), Aspek Dasar Agronomi Berkelanjutan (Cetakan I, pp. 3783). Gadjah Mada University Press.

Turner, N. (1997). Further progress in crop water raltion. Advance Agronomy 58.

Vitousex, P. M., Cassman, K., Cleveland, C., 
Crews, T., Field, C. B., Grimm, N. B., Howart, R.W., Marino, R., Martinelli, L., Rastetter, E.B., \& Sprent, J. I. (2002). Towards an ecological understanding of biological nitrogen fixation. Biogeochemistry, 57(1), 145. https://doi.org/10.1023/A:1015798428743

Wijewardana, C., Reddy, Raja, K., \& Bellaloui, N. (2018). Soybean Seed Physiology, Quality, and Chemical Composition under Soil Moisture Stress. Food Chemistry, 278, 92-100. https://doi.org/10.1016/j.foodchem.2018.11.0 35

Yordanov, I., Vellikova, V., \& Tsonev, T. (2000). Plant Responses to Drought, Acclimation, and Stress Tolerance. Photosynthetica, 38(1), 171186. https://doi.org/10.1023/A:10072014114 74

Zandstra, H. G. (1982). Effect of soil moisture and texture on growth of upland crops wetland rice. Inst. Los Banos. Philiphines.
Zelalem, A., Tekalign, T., \& Nigussie, D. (2009). Response of potato (Solanum tuberosum L.) to Different Rates of Nitrogen and Phosphorus Fertilization On Vertisols at Debre Berhan, In the Central Highlands of Ethiopia. Afr. J. Pl. Sci., 3(2), 16-24. http://dx.doi.org/10.4172 /2329-8863.1000250

Zhu, X. C., Song, F. B., Liu, S. Q., Liu, T. D., \& Zhou, X. (2012). Arbuscular mycorrhizae improves photosynthesis and water status of Zea mays L. under drought stress. Plant Soil Environ, 58(4), 186-191. https://doi.org/ 10.17221/23/2011-PSE

Zou, L., Sun, X., Zhang, Z., Liu, P., Wu, J., Tian, C., Qiu, J., \& Lu, T. (2011). Leaf Rolling Controlled by the Homeodomain Leucine Zipper Class IV Gene Roc5 in Rice1. Plant Physiology, 156(7), 1589-1602. https://doi. org/10.1104/pp.111.176016 